\title{
RUBY AND SAPPHIRE FROM THE SOUTHERn URAL MOUNTAINS, RusSia
}

By Alexander J. Kissin

\begin{abstract}
Primary occurrences of ruby, pink sapphire, sapphires of other colors, and spinel have been found in marbles in the Ural Mountains. This article describes one occurrence, at Kootchinskoye, in the southern Urals, as a model for others in the Ural Mountains. Study of Kootchinskoye also gives some guidelines for predicting other ruby deposits. Although at present, there is no commercial production in this area, it appears to bave significant potential.
\end{abstract}

Following the 1825 discovery of alluvial gold in the Kamenka and Sanarka River basins of the southern Ural Mountains, numerous gem materials were found in the course of gold mining. These include beryl, chrysoberyl, corundum, diamond, euclase, topaz, and tourmaline. As a result, Professor N. I. Koksharov (1855) referred to the region as the "Russian Brazil." Corundum from placers in the area was first reported by Barbot de Marny (1855). The specimens were relatively large (pink and blue sapphire up to $10 \times 20 \mathrm{~mm}$; ruby up to $10 \mathrm{~mm}$ ) but not of gem quality. It was assumed within the geologic community that they originated in pegmatites,

\section{ABOUT THE AUTHOR}

Dr. Kissin is a senior researcher in the Laboratory of Geochemistry, Institute of Geology and Geochemistry, of the Urals Branch of the Russian Academy of Sciences (IGG UrB RAS), Ekaterinburg, Russia.

Acknowledgments: The author is grateful to $E$. Soroka of the Laboratory of Geochemistry, IGG UrB RAS, and K. N. Hurwit, of the GIA Gem Trade Laboratory, for their help in preparing this article for publication. V. G. Gmyra, IGG UrB RAS, performed the microprobe analyses of the corundum and spinel samples. The marbles were analyzed by the Central Analytical Laboratory and the Polevskaia Laboratory of the Geological Committee "Uralgeologia."

Gems \& Gemology, Vol. 30, No. 4, pp. 243-252.

(C) 1995 Gemological Institute of America which are abundant in the area, although no corundum had been observed in situ.

In 1978, the present author postulated in the course of his studies that the ruby may have originated in marbles, which are also widespread in the area. This would be analogous to the occurrence of corundum in marbles at localities such as Mogok, Myanmar (see, e.g., Kane and Kammerling, 1992), from which some of the world's finest rubies are mined. Consequently, in 1979, the author traveled to the Kootchinskoye marble quarry, where he discovered ruby, pink sapphire, and other varieties of corundum in situ (figure 1). In 1983, ruby and several varieties of sapphire were found in marble at Chooksinsokoye near the village of Chooksa (here, in alluvial deposits as well as in situl and at Svetlinskoye. In 1988, three additional primary and five alluvial occurrences were found in, or associated with, marbles. The gem-bearing rocks occur in a linear belt about $600 \mathrm{~km}$ long (figure 2).

Ruby and sapphire mineralization is now known to occur in marbles within four metamorphic complexes in the Ural Mountains: Murzinsko-Aduiskii, Kochkarskii, Jabyk-Karagaiskii, and Suundukskii |figure 3). On the basis of the known geology, other potential ruby- and sapphire-bearing areas are believed to exist in the Urals. Thus, the Ural Mountains represent an extensive new area of gem corundum mineraliza- 
Figure 1. These ruby crystals were found at the Kootchinskoye marble quarry in the Southern Ural Mountains of Russia. They average $1 \times 2 \mathrm{~mm}$ and belong to

the "type A" category of gem corundum from this area. Photo (C) GIA and Tino Hammid

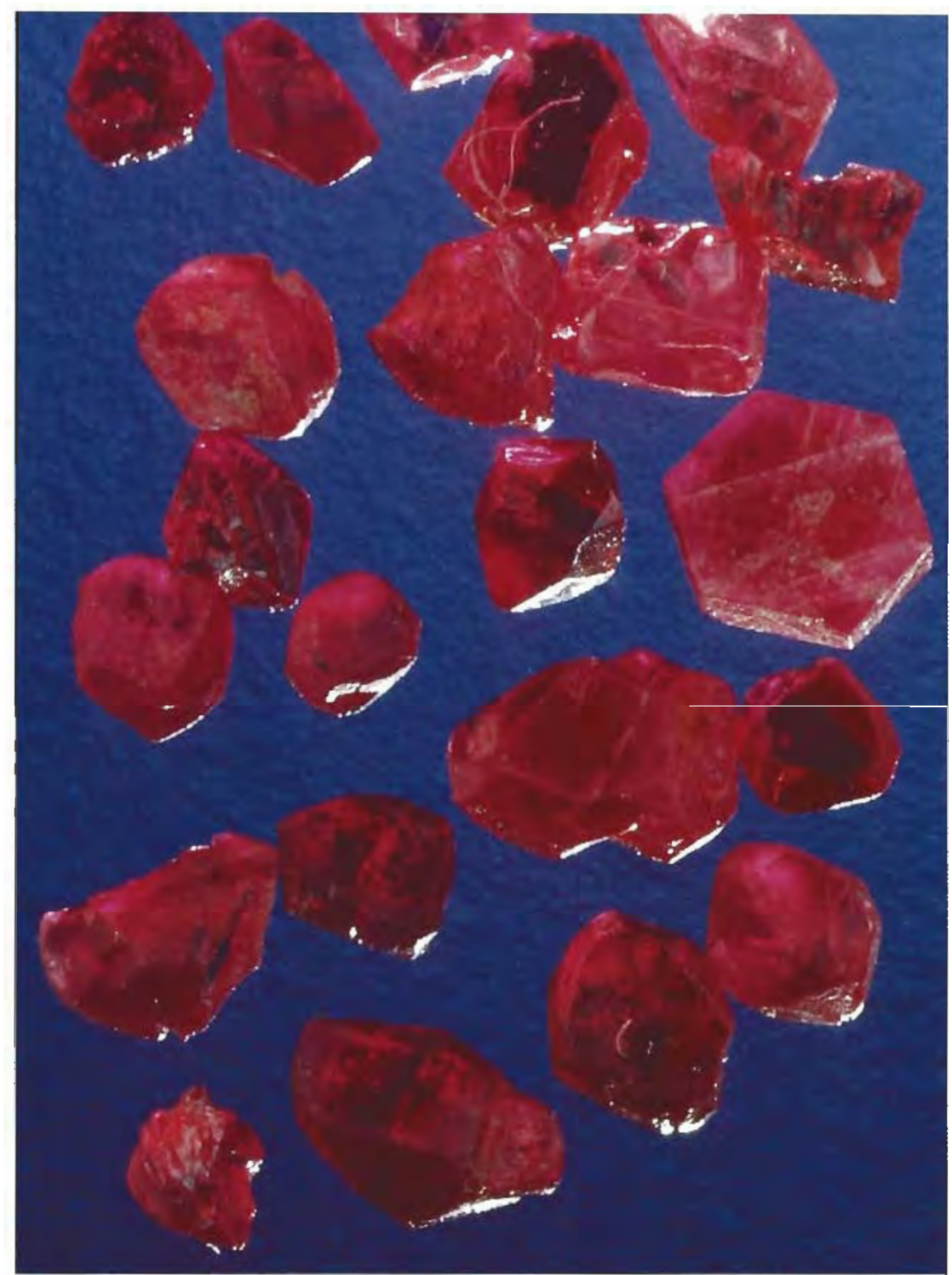

tion that has been called the "Uralian ruby-bearing province" (Kissin, 1990a). To date, approximately 100-150 carats of facet-grade corundum have been recovered and fashioned at various facilities (Ekaterinburg, Moscow, and an undisclosed location in Czechoslovakia) for evaluation purposes.

This article describes the results of a study conducted to better understand the geologic environment of this gem deposit and provide a basis for further exploration in the area. It reports on the geologic conditions and constraints relating to the formation of the presently known Ural Mountain ruby occurrences, especially at the Kootchinskoye deposit. Also provided are some gemological properties of gem corundum produced to date. Although ruby and sapphire are not yet commercially extracted from this area, it is expected that exploration will successfully find more deposits, some of which eventually will become active mines.

\section{LOCATION AND ACCESS}

The Kootchinskoye marble quarry (figure 4), which measures about $100 \mathrm{~m} \times 40 \mathrm{~m}$ (330 feet $\times 132$ feet), is located on the eastern side of the Ural Mountains, in the moderately wooded southern part about 50 $\mathrm{km}$ from the highest peaks in the range. The region consists of both flat and hilly areas with maximum relief of 300-380 m. Annual temperatures range from $-12^{\circ}$ to $-50^{\circ} \mathrm{C}\left(10^{\circ}\right.$ to $\left.-58^{\circ} \mathrm{F}\right)$ in the winter, when the ground freezes to a depth of $1.5 \mathrm{~m}$ (5 feet), and from $17^{\circ}$ to $35^{\circ} \mathrm{C}\left(63^{\circ}-95^{\circ} \mathrm{F}\right)$ in the summer. Although there are a few small rivers in the area, there are no major rivers or lakes. Plast, about $15 \mathrm{~km}$ from the Kootchinskoye deposit, is the largest town in the vicinity (population: approximately 50,000); Chelyabinsk-about $120 \mathrm{~km}$ to the north-is the largest city (population: about 1.2 million). The deposits can be reached by auto or train from all major population centers (e.g., Ekaterinburg, Chelyabinsk) in the region.

\section{GEOLOGIC SETTING OF THE KOOTCHINSKOYE OCCURRENCE}

Because rubies and sapphires were first discovered in situ at Kootchinskoye, it has been the object of more geologic studies than any of the other occurrences in 
Figure 2. The rocks containing ruby and sapphire occur in a 600-km linear belt (shown in orange on the inset) in Russia's southern Ural Mountains. Most deposits located thus fat are near Ekaterinburg and Chelyabinsk. The Kootchinskoye deposit, on which most geologic studies have been conducted, is near the town of Plast.

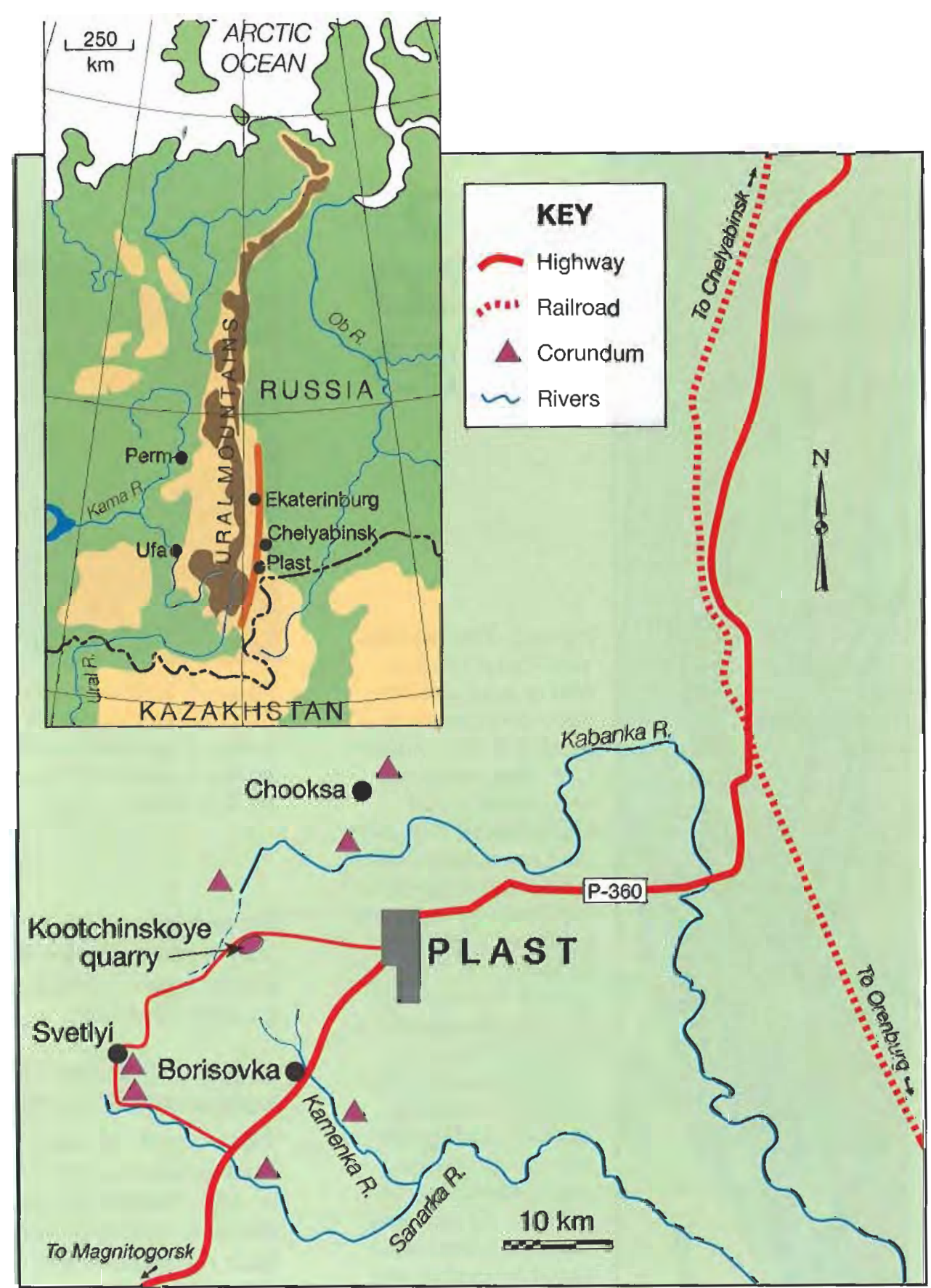

this region. It appears to be representative of other ruby-bearing marble occurrences in the Ural Mountains. Therefore, it is used here as a model of such occurrences and to describe the geologic conditions under which corundum formed.

The Kootchinskoye ruby/sapphire deposit occurs at the edge of the Kochkarskii metamorphic complex (again, see figure 3), which is of Middle to Upper Paleozoic in age. Metamorphism began about 300 My ago, with the first-prograde (higher pressure or temperature)-stage lasting no more than 30 $\mathrm{My}$, and the last - retrograde flower pressure or temperature)-stage ending about $260 \mathrm{My}$ ago. Structurally, the complex is characterized by domes between which are tectonically formed depressions known as graben-synclines, which are bounded by formations dipping inward like those of a syncline. The domes usually are formed in gneisses and granites, whereas the graben-synclines characteristically are formed in schists, amphibolites, and marbles; both have numerous fracture and fault zones (figure 5). In places, granite dikes and pegmatites are widespread, as is silicification in the fracture systems, with some occurrence of pink topaz and green tourmaline. Metamorphic amphibolite facies rocks /typical of moderate-to-high pressure and high-temperature regional metamorphism) have been identified in the domal structures, whereas metamorphic albite-epidote-amphibolite facies rocks fformed under lower pressures and temperatures) occur in 

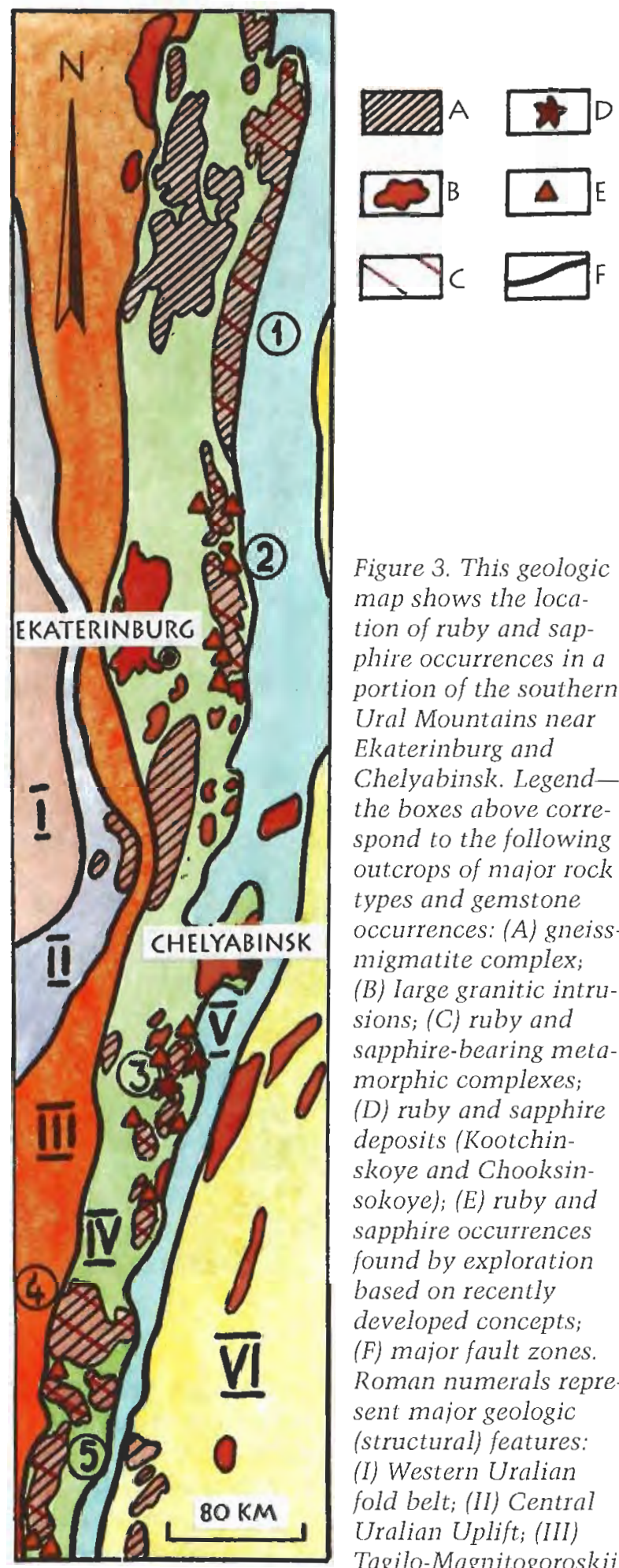

Figure 3. This geologic map shows the location of ruby and sapphire occurrences in a portion of the southern Ural Mountains near

Ekaterinburg and Chelyabinsk. Legendthe boxes above correspond to the following outcrops of major rock types and gemstone occurrences: (A) gneissmigmatite complex; (B) Iarge granitic intrusions; (C) ruby and sapphire-bearing metamorphic complexes; (D) ruby and sapphire deposits (Kootchinskoye and Chooksinsokoye); (E) ruby and sapphire occurrences found by exploration based on recently developed concepts; (F) major fault zones. Roman numerals represent major geologic (structural) features: (I) Western Uralian fold belt; (II) Central Uralian Uplift; (III) Tagilo-Magnitogoroskii trough (downwarp); (IV) Eastern Uralian Uplift; (V) Eastern Uralian trough; (Vl) Transuralian Uplift. Circled Arabic numerals refer to gneissic-migmatitic complexes containing marbles with gemstone varieties of corundum: (1) Gaievskii (Sosvinskii and Medvedevsko-Saldinskii)—no gem corundums found yet but potential is good; (2) Murzinsko-Aduiskii; (3) Kochkarskii; (4) Jabyk-Karagaiskii; (5) Suundukskii. Watercolor by A. J. Kissin.

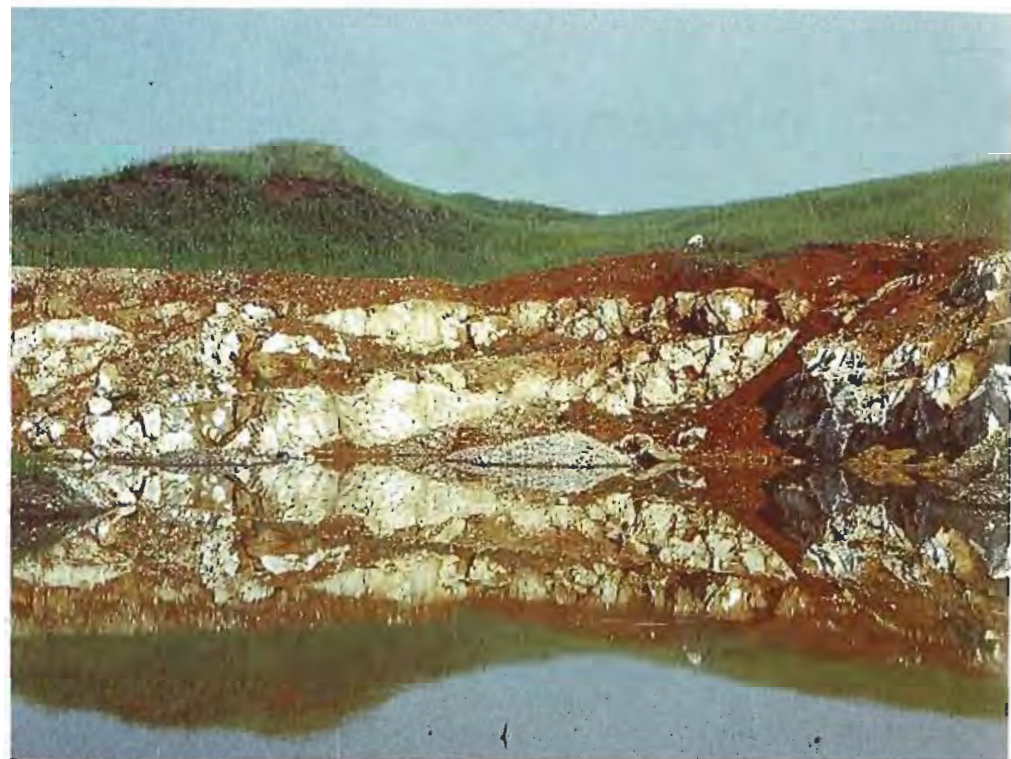

Figure 4. Light-colored calcite marble in Kootchinskoye quarry's north wall is representative of material in which ruby occurs. The quarry is filled with water $5-7 \mathrm{~m}$ deep. Photo by A. J. Kissin.

the graben-syncline structures. The Kootchinskoye ruby-sapphire deposit is located in the axial part of a graben-syncline structure in which marbles are particularly abundant.

\section{CHARACTERISTIC FEATURES OF THE KOOTCHINSKOYE MARBLES}

Three types of marble have been identified at Kootchinskoye, by means of wet-chemical analyses of 150 marble specimens and semi-quantitative emission spectrographic analyses on 90 marbles. Each represents a different set of metamorphic conditions (or reactions; Kissin 1990b, 1991).

Calcite Marble. This light-colored, massive, medium-grained marble is composed of anhedral calcite crystals. Polysynthetic twinning is rare. It contains less than $0.05 \mathrm{wt} \% \mathrm{MgO}$. Accessory minerals include quartz, adularia, fuchsite (chromian muscovite), green tourmaline, amphibole, graphite, pyrite, pyrrhotite, sphalerite, galena, hematite, and chlorite. Corundum is not found in this type of marble.

Magnesian Calcite Marble. This marble is typically variegated light blue, light green, white, and gray, and is composed of interlocking aggregates of medium- to coarse-grained euhedral calcite crystals that are highly deformed and do exhibit polysynthetic twinning. Magnesian calcite marble occurs inter- 


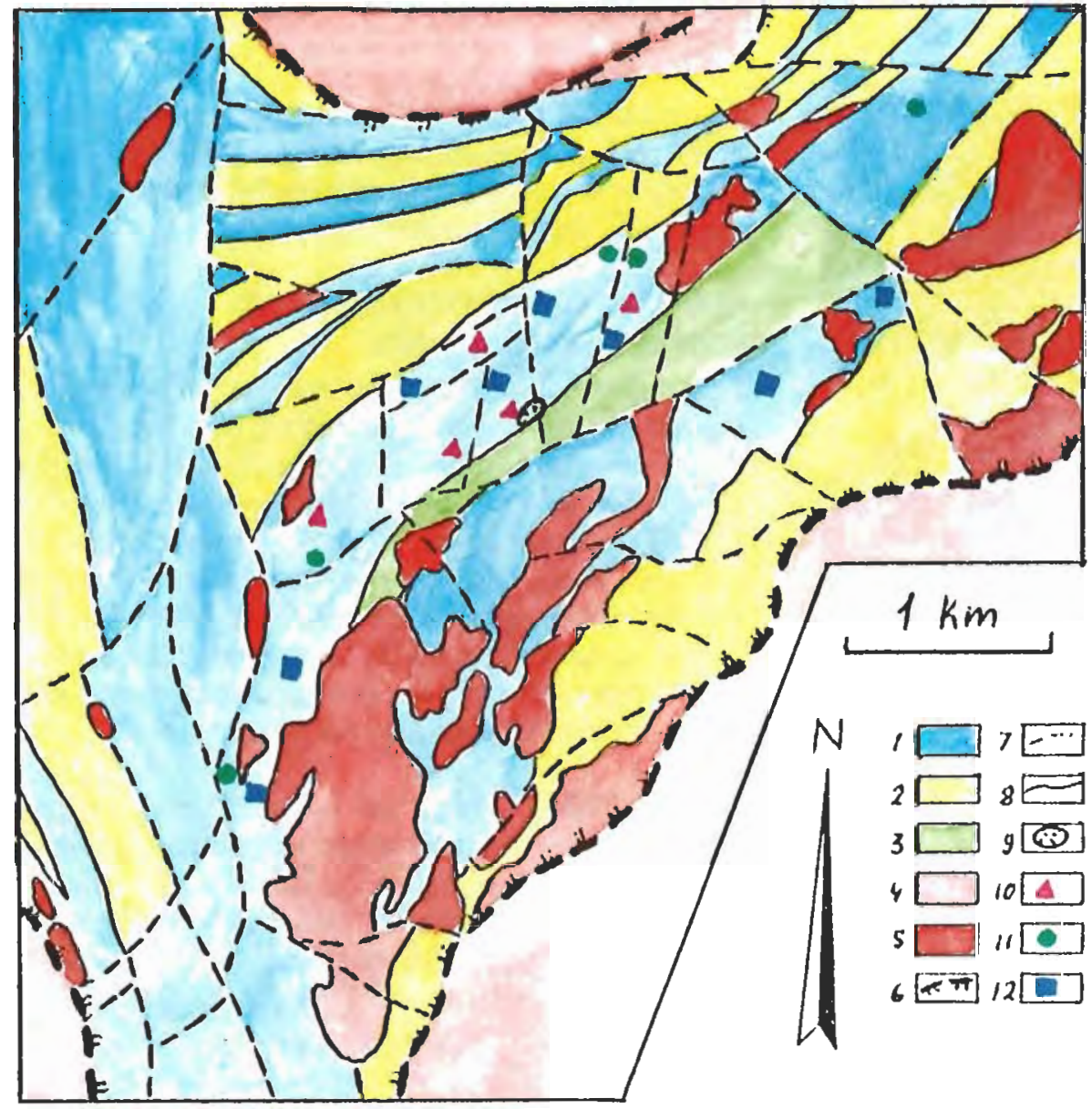

Figure 5. This geologic map of the Kootchinskoye ruby-sapphire occurrence was compiled by the author. The numbered boxes and lines in the key correspond to similar colored areas and lines in the map. The numbers represent: (1) marbles with schist lenses; (2) schists with marble lenses; (3) amphibolites and amphibole schists; (4) gneisses and schists; (5) minor granitoid intrusions; (6) fault zones; (7) fractures; (8) rock-unit contacts/boundaries: (9) the Kootchinskoye quarry; (10) type-A ruby occurrence; (11) type- $B$ pink sapphire occurrence; (12) type-C sapphire occurrence. Watercolor by A. J. Kissin. grown with calcite marble; both have gradational boundaries. The $\mathrm{MgO}$ content of magnesian calcite marble ranges from 0.1 to 0.9 wt.\%. This type of marble does contain corundum and other accessory minerals, such as spinel, apatite, pyrite, pyrrhotite, rutile, fluorite, green tourmaline, Cr-pargasite (an amphibole), sulfur, margarite, diaspore, anhydrite, tsavorite, phlogopite, and Al-chlorite.

Dolomitic Calcite Marble. This white to light-yellow, fine-grained rock has a poikiloblastic texture (i.e., one in which small grains of one mineral occur with larger grains of another mineral). Inclusions (or relicts) of magnesian calcite marble are often observed in the dolomitic calcite marble, which itself occurs as lenses or veins for occupying fractures) as much as $2 \mathrm{~m}$ wide in the magnesian calcite marble. The $\mathrm{MgO}$ content of dolomitic calcite marble always exceeds $1.0 \mathrm{wt} \%$ and may reach almost 22 wt.\%, depending on the amount of dolomite (pure dolomite contains $21.86 \mathrm{wt} \% \mathrm{MgO}$ ). This marble also contains corundum, as well as accessory minerals such as spinel, pyrite, rutile, phlogopite, tourmaline, Cr-pargasite, sphene, fluorite, norbergite, graphite, Al-chlorite, and tremolite.

Calcite marble, which is widespread in the Kochkarskii metamorphic complex, formed by recrystallization of limestone during prograde (high-pressure) metamorphism. Magnesian calcite marble is locally abundant at Koochinskoye, intergrown with calcite marble; it formed during prograde metamorphism accompanied by the introduction of fluids. Dolomitic calcite marble formed by magnesium metasomatism in the magnesian calcite marble during retrograde (lower pressure/temperature) metamorphism.

\section{MATERIALS AND METHODS}

This study is based on the microscopic examination of approximately 11,000 heavy-mineral concentrates, and approximately 500 insoluble residues, obtained after hydrochloric acid treatment of marbles. The concentrates (see, e.g., figure 6) ranged from several milligrams to a few kilograms. Average grain size ranged from 1.0 to $2.7 \mathrm{~mm}$. Morphological and other characteristics of several thousand corundum specimens from Kootchinskoye were studied. 


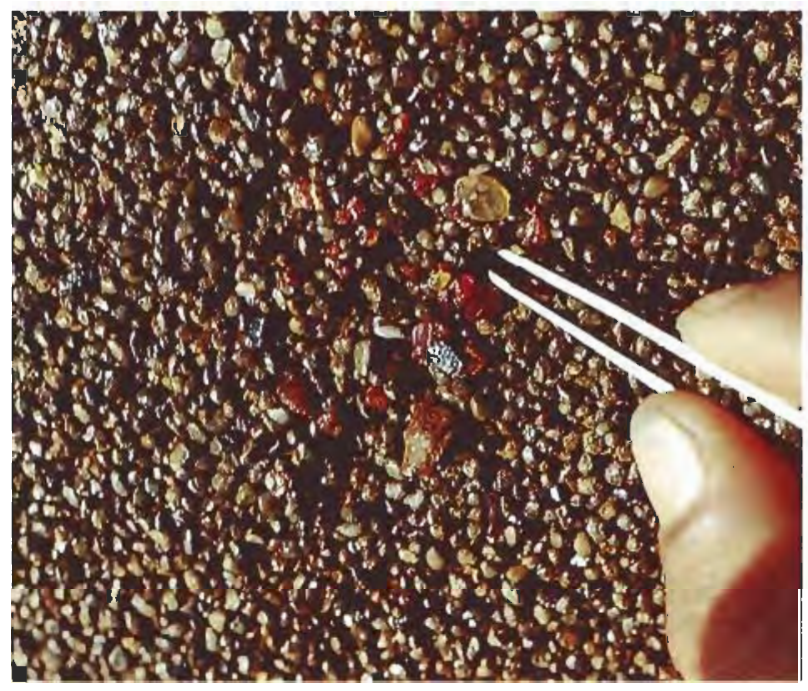

Figure 6. This sample, which contains ruby, spinel, and chrysoberyl, is representative of concentrate that was obtained from $1 \mathrm{~m}^{3}$ of gravel recovered from Kootchinskoye. Grain sizes range from 1.0 to $2.7 \mathrm{~mm}$

Their inclusions were identified primarily by microprobe analysis of thin sections and the morphology of the crystals. Refractive indices were determined on 30 samples using a polarizing microscope with calibrated immersion liquids. In addition, six corundum specimens were analyzed by wet chemistry. For the purpose of this article, microprobe analyses (using a IXA-5 electron microprobe) were performed on 11 pink and red corundum and 11 dark red, purple-red, and pink spinel samples from Kootchinskoye; each was approximately $1-2 \mathrm{~mm}$.

\section{RESULTS: THE KOOTCHINSKOYE RUBIES AND SAPPHIRES}

The rubies and sapphires recovered from the Kootchinskoye deposit appear to fall into three categories, designated types A, B, and C (Kissin, 1991). Table 1 lists selected physical and optical properties, as well as chromium content, of the three types of gem corundum. Only types A and B have the color and clarity appropriate for facet-grade material; type $\mathrm{C}$ may be suitable for use as cabochons. Table 2 provides the results of the electron microprobe analyses of 11 gem corundums from the same deposit.

Type A (Ruby). This type typically ranges from bright red to purplish red (again, see figure 1) and has a thick, platy habit (figure 7). Crystals are usually well formed, but "case-like" skeletal forms (i.e., hollow crystals filled with the host rock) are often observed. The surfaces of the crystals are frequently highly reflective. Although the crystals are transparent, they have prominent striae. The crystal faces c (0001) and $r(10 \overline{1} 1)$ are well developed, as occasionally are $n(22 \overline{4} 3)$ and $a(11 \overline{2} 0)$. Aggregates of crystals are rarely observed and, when encountered, do not consist of more than three individuals.

TABLE 1. Properties of ruby and sapphires from the marbles at the Kootchinskoye occurrence in the southern Ural Mountains.

\begin{tabular}{|c|c|c|c|}
\hline Property & Type A — Ruby & Type B - Pink sapphire & $\begin{array}{l}\text { Type C-Sapphire, } \\
\text { pink sapphire, ruby }\end{array}$ \\
\hline Color & $\begin{array}{l}\text { Red (varies from "crimson" } \\
\text { red to red-violet) }\end{array}$ & $\begin{array}{l}\text { Pink (varies from pale to dark } \\
\text { pink with local areas of blue) }\end{array}$ & $\begin{array}{l}\text { Light colors to blue, red, } \\
\text { and brown or coloriess }\end{array}$ \\
\hline Habit & $\begin{array}{l}\text { Thick, platy; well-formed crystals; striae } \\
\text { from rhombohedral twinning common }\end{array}$ & $\begin{array}{l}\text { Typically round; occasional } \\
\text { acicular crystals }\end{array}$ & $\begin{array}{l}\text { Massive; rounded; irregular - } \\
\text { can be well formed, but rare }\end{array}$ \\
\hline Crystal faces & $\begin{array}{l}c \text { (0001) and } r(1011) \text { well developed; } \\
\text { occasionally } n \text { (22) } 3 \text { ) and } a(11 \overline{20})\end{array}$ & $c(0001)$ and $a(11 \overline{2})$ & None or seldom \\
\hline Transparency & Transparent & Transparent & Generally translucent to opaque ${ }^{n}$ \\
\hline Fractures & Usually fractured & No fractures & Fractures rare \\
\hline Inclusions & Oclahedral pyrite and apatite, gas & $\begin{array}{l}\text { Octahedral and pentagonal pyrite } \\
\text { and black rutile, gas }\end{array}$ & $\begin{array}{l}\text { Pentagonal pyrite, red rutile, } \\
\text { phlogopite, graphite, gas, liquid, etc. }\end{array}$ \\
\hline Typical weight & $1 \mathrm{ct}$ & Less than $1 \mathrm{ct}$ & Variable - can be extremely large \\
\hline Aggregates & $\begin{array}{l}\text { Rarely observed; not more } \\
\text { than } 3 \text { individuals when found }\end{array}$ & Up to 8-10 individual crystals & May be fine-grained aggregates \\
\hline Refractive indices ${ }^{\circ}$ & 1.771 and $1.760 ; 1.772$ and 1.760 & 1.767 and 1.758 & 1.767 and 1.759 \\
\hline Birefringence $^{b}$ & $0.011-0.013$ & 0.009 & 0.008 \\
\hline $\mathrm{Cr}_{2} \mathrm{O}_{3}$ content & $1.22-2.81$ wt. $\%$ & $0.11-0.51$ wt. $\%$ & $0.03-0.27 w t . \%$ \\
\hline Jewelry potential & Very good & Good & Poor; for cabochons only ${ }^{\circ}$ \\
\hline
\end{tabular}

aHas been found to be transparent, facefing quality at other deposits, such as at Lipovskoye in the central Urals.

${ }^{b}$ As determined with a polanizing microscope using refractive-index liquids. 


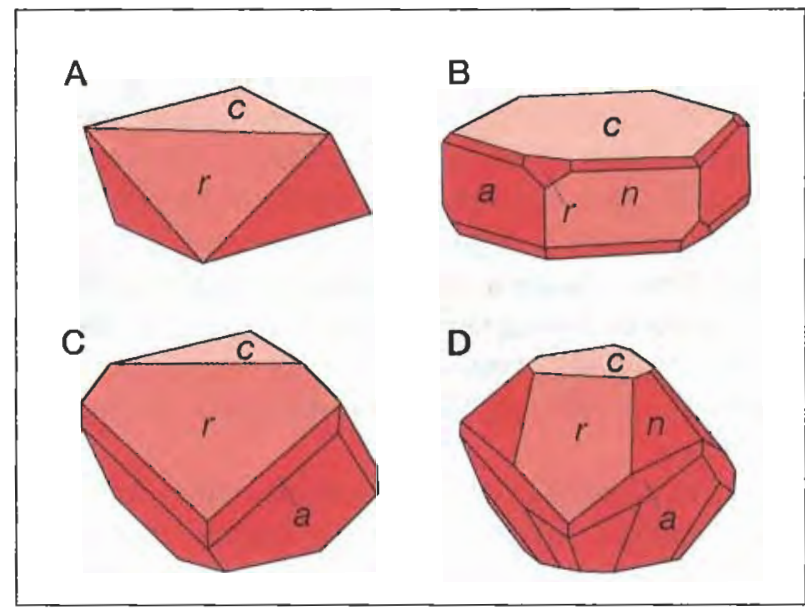

Figure 7. Characteristic crystal forms of type- $A$ (ruby) corundum. Type-A rubies typically occur in "flattened" crystals, whereas type-B rubies are usually rounded.

Inclusions of pyrite (with a combination of octahedron and pyritohedron forms) and apatite have been observed, but no carbonate inclusions were seen in other than the skeletal crystals. These rubies may weigh as much as several carats /the largest so far observed weighed $120 \mathrm{ct}$ ); however, those of gem quality typically are $1 \mathrm{ct}$ or less.

Note that the indices of refraction vary with the $\mathrm{Cr}_{2} \mathrm{O}_{3}$ content, in agreement with published data. Birefringence was considerably higher in the type- $\mathrm{A}$ rubies than in their type- $\mathrm{B}$ and type- $\mathrm{C}$ counterparts. As is to be expected based on the color appearance, $\mathrm{Cr}_{2} \mathrm{O}_{3}$ content was usually significantly higher in the type-A material than in types $\mathrm{B}$ or $\mathrm{C}$, although the author has analyzed some type- $\mathrm{C}$ corundum with a relatively high $\mathrm{Cr}_{2} \mathrm{O}_{3}$ content.

Type B (Pink Sapphire). This type of gem corundum ranges from pale pink to dark pink, with local areas of blue (figure 8). Crystals are typically round; occasionally, however, well-formed elongated crystals with well-developed $c(0001)$ and $a(11 \overline{2} 0)$ faces are observed. The crystals are usually transparent and have few or no fractures. Pyrite (with octahedron and pyritohedron faces) and short, black-appearing rutile crystals are typically found as inclusions. Type-B pink sapphire is usually smaller than type-A ruby.

Type C (Other Sapphires). Type-C corundum can be red, pink (figure 9), brown, yellow, blue, violet, or

Figure 8. Type-B pink sapphires from the Kootchinskoye deposit. These crystals average $0.5 \times 1 \mathrm{~mm}$. Photo (C) GIA and Tino Hammid.

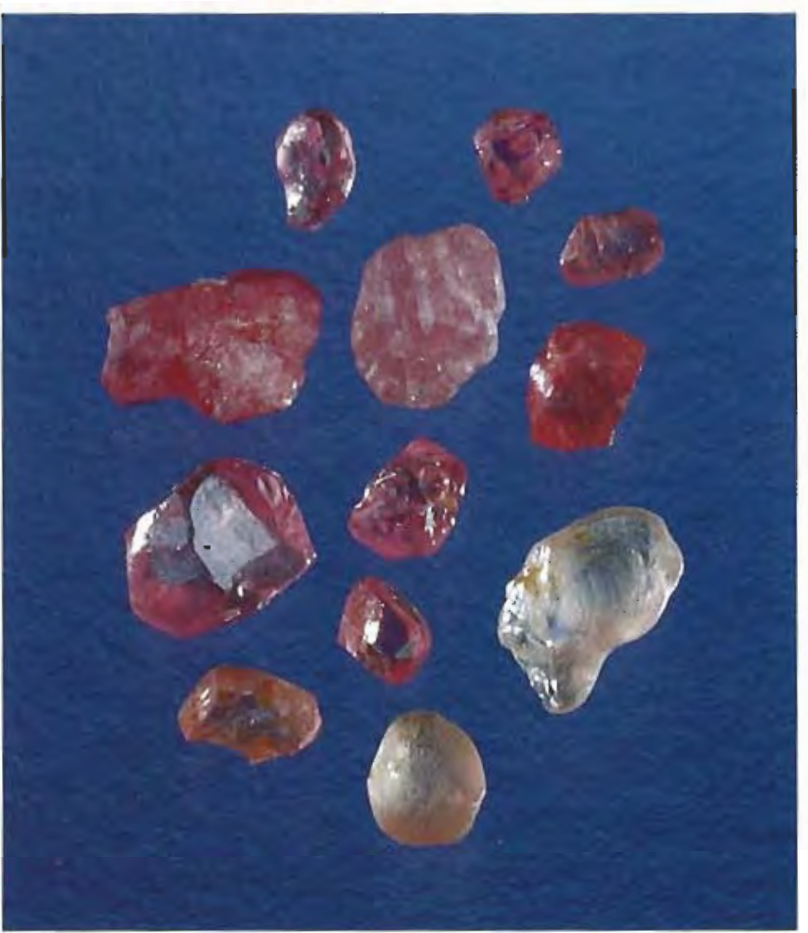

TABLE 2. Results of electron microprobe analyses ${ }^{a}$ of gem corundums from the Kootchinskoye occurrence.

\begin{tabular}{|c|c|c|c|c|c|c|c|c|c|c|c|}
\hline \multirow[t]{2}{*}{ Oxide (wt.\%) } & \multicolumn{3}{|c|}{ Type A (red) } & \multicolumn{4}{|c|}{ Type B (pale-dark pink) } & \multirow[b]{2}{*}{8} & \multicolumn{3}{|c|}{ Type C (colorless-pink) } \\
\hline & 1 & 2 & 3 & 4 & 5 & 6 & 7 & & 9 & 10 & 11 \\
\hline $\mathrm{Al}_{2} \mathrm{O}_{3}$ & 96.38 & 95.69 & 96.75 & 98.89 & 98.33 & 98.43 & 98.28 & 98.11 & 98.44 & 98.06 & 98.33 \\
\hline $\mathrm{FeO}^{\circ}$ & 0.00 & 0.00 & 0.01 & 0.04 & 0.00 & 0.00 & 0.00 & 0.00 & 0.07 & 0.00 & 0.00 \\
\hline $\mathrm{MgO}$ & 0.00 & 0.01 & 0.00 & 0.00 & 0.00 & 0.00 & 0.00 & 0.12 & 0.00 & 0.02 & 0.00 \\
\hline $\mathrm{Cr}_{2} \mathrm{O}_{3}$ & 1.92 & 2.81 & 1.22 & 0.21 & 0.38 & 0.11 & 0.51 & 0.35 & 0.07 & 0.03 & 0.27 \\
\hline
\end{tabular}

"Anaiyses were performed by Valentina Gmyra of the Institute of Geokogy and Geochemistry of the Urals Branch of the Russian Academy of Sciences on a JXA-5 eiectron microprobe operating at $20 \mathrm{keV}$, a current of $10 \mathrm{nA}$; standard ZAF corrections were made Note that vanadium (as $\mathrm{V}_{2} \mathrm{O}_{3}$ ) was checked, but none was found in any specimen.

"Total iron as FeO 


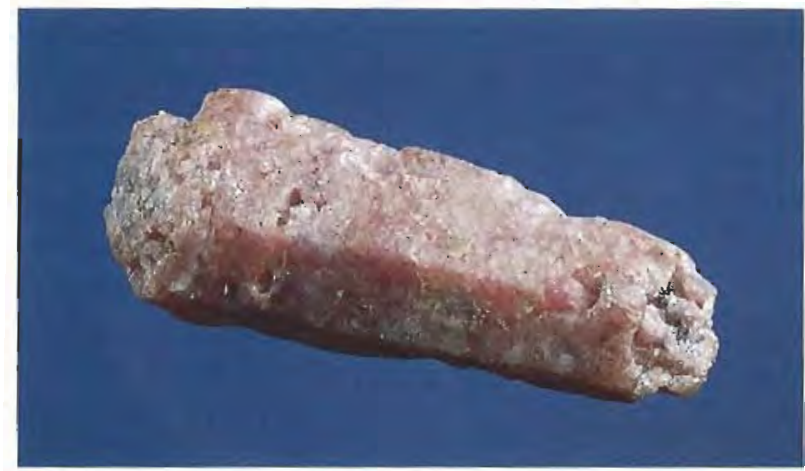

Figure 9. This 3-cm-long crystal has the poor diaphaneity associated with type-C corundum from Kootchinskoye. Photo (C) GIA and Tino Hammid.

colorless. At Kootchinskoye, the crystals are usually irregular in shape and translucent to opaque. Fractures are rarely observed, but the presence of many inclusions (gas, liquid, long red rutile needles, phlogopite, graphite, pentagonal pyrite, etc.) contributes to the typically poor diaphaneity. (Note, however, that facet-grade type-C crystals have been recovered recently from a new deposit at Lipovskoye.) Large specimens $(8-10 \mathrm{~mm}$; rarely up to $50 \mathrm{~mm}$ ) of this corundum have been observed.

\section{CONDITIONS FOR THE FORMATION OF THE RUBY AND SAPPHIRE}

The different corundum types appear related to specific types of marble and especially the specific (metamorphic) conditions of temperature and pressure to which the host rock has been exposed. Geobarometry studies conducted by the author (based on the dolomite-calcite technique described by Talantsev, 1981) revealed that the dolomitic calcite marble formed at a temperature in the range of $620^{\circ}-660^{\circ} \mathrm{C}$ and a pressure of about $2.5 \mathrm{kbar}$ (Kissin and Talantsev, 1986). These values, which probably represent the highest temperatures and pressures attained in the area, correspond well to the metamorphic conditions determined for the Kochkarskii metamorphic complex by Boltyrov et al. (1973).

Theoretical and experimental studies of the reaction

corundum + dolomite $\longleftrightarrow$ spinel + calcite $+\mathrm{CO}_{2}$ reveal that the temperature and pressure at which the above reaction will proceed, and which mineral(s) will be found in the marbles, depends on: (a) $\mathrm{CO}_{2}$ pressure, and (b) magnesium activity (roughly proportional to the concentration of magnesium in a rock; magnesium is available in dolomite-Pertsev, 1977; Jansen et al., 1978; Thordarsson, 1981). These studies have shown that as the temperature increases, the reaction moves to the right (spinel is formed), and as the pressure increases, the reaction moves to the left (corundum forms). Further, if the magnesium activity is increased, a corresponding increase in $\mathrm{CO}_{2}$ pressure is required for the corundum to be stable. Thus, changes in temperature and $\mathrm{CO}_{2}$ pressure, as occur during the various stages of metamorphism (prograde, retrograde), may have a major influence on the stability of minerals, including corundum.

At Kootchinskoye, type-A ruby formed in magnesian calcite marbles during prograde metamorphism as a result of fluid activity on limestone. During subsequent retrograde metamorphism of the magnesian calcite marble, which resulted in the formation of dolomitic calcite marble, most type-A ruby was converted to spinel. The type-A ruby that survived usually is strongly fractured (as a result of prograde metamorphism) and sometimes shows polysynthetic twinning.

Type-B pink sapphire formed during an early stage of retrograde metamorphism of magnesian calcite and dolomitic calcite marbles. This sapphire formed simultaneously with the marbles; however, where the marble has a high magnesium content, spinel is more likely to have formed than pink sapphire. Because compressive stress was minimal during the retrograde metamorphism, type-B pink sapphire typically does not have fractures.

Type-C sapphire was formed under conditions of decreasing temperature, changes in the fluid regime (increasing role of $\mathrm{H}_{2} \mathrm{O}$ ), and high $\mathrm{CO}_{2}$ pressure. It formed in, and filled, fractures in both the magnesian calcite and dolomitic calcite marbles. When the $\mathrm{CO}_{2}$ pressure decreased, orangy red spinel formed instead of corundum. Thus, spinel is found in both types of marble, where it replaced ruby and pink sapphire that formed earlier. However, the replacement is incomplete and only occurs near (i.e., within 1-2 $\mathrm{mm}$ of fractures in the host marble. Beyond this distance, the corundum and spinel are unaffected.

\section{DISCUSSION}

Ruby and sapphire from marble deposits have been known for more than a dozen centuries (see, e.g., Kane and Kammerling, 1992). However, relatively little is known of the origin of these deposits. Based on the study of published geologic data, it appears that the ruby and sapphire deposits in Myanmar (Iyer, 1953; Keller, 1983; Kane and Kammerling, 1992), Pakistan (Okrusch et al., 1976; Gübelin, 1982), Afghanistan (Rossovskii, 1980), and Tanzania (Hänni 
and Schmetzer, 1991) have many similarities, and may be analogous, to those at Kootchinskoye and elsewhere in the Ural Mountains. All these Russian deposits occur in marble (frequently in several distinct types). Two types of ruby (and sapphire), as well as spinel, have been recognized in most of them (Rossovskii et al., 1982). In the case of the Uralian deposits, of which Kootchinskoye is a representative example, the three types of ruby and sapphire (types $A, B$, and $C$ ) are rarely found together. Although metamorphism (i.e., significant changes in temperature and pressure) is the main geologic factor in the formation of the ruby and sapphire, other factors are also important. In particular, the magnesium content of the marble will have a major influence on whether spinel is the preferred (stable) mineral phase. The $\mathrm{Al}_{2} \mathrm{O}_{3}$ content of the marble does not seem to be a critical factor, inasmuch as this component is low in all three types of ruby- and sapphire-bearing marble at Kootchinskoye; in fact, the $\mathrm{Al}_{2} \mathrm{O}_{3}$ content of the gem-bearing marbles $(0.08-0.13$ wt. \%) is lower than that of nearby marble that does not contain corundum (0.15-0.18 wt.\%).

Some investigators have suggested that the ruby-sapphire mineralization in marble developed as a result of the contact metamorphic action of pegmatites or granites on aluminum-hearing rocks (e.g., Kievlenko et al., 1974). However, such does not appear to be the case, at least with the Uralian deposits, because at some of these deposits pegmatites and granites are either rare or absent. In the author's experience, where contact zones between pegmatites and marble or aluminum-bearing rocks have been observed, ruby and sapphire are rarely found.

\section{CONCLUSIONS}

Rubies and sapphires have been recovered from different types of marbles in the Ural Mountains. The site where they were first discovered, Kootchinskoye, serves as a model for other deposits found in the Urals. On the basis of gemological and chemical

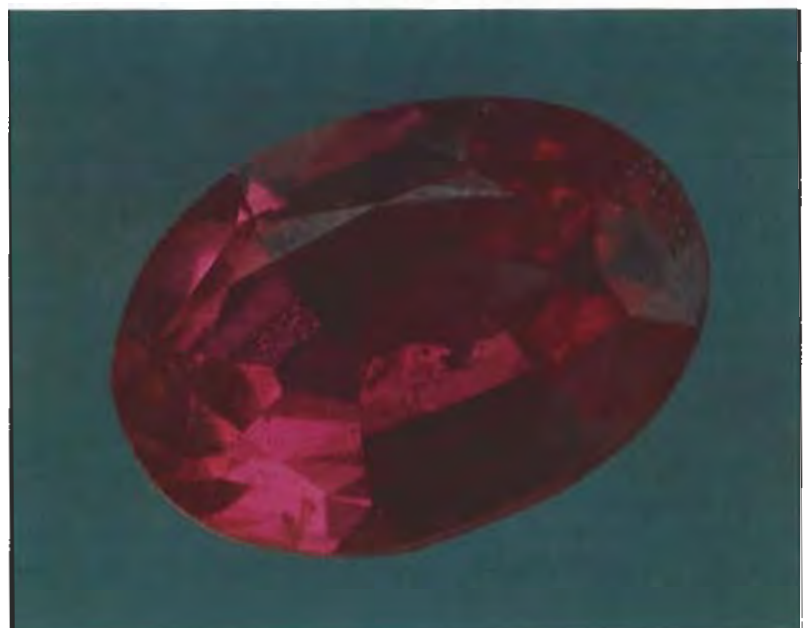

Figure 10. This 0.3-ct ruby was recovered from a relatively recent occurrence at Lipovskoye in the central Urals.

studies, the author has identified three types of gem corundum-ruby and various colors of sapphireswhich occur in two of the three types of marble that have also been identified in this highly metamorphosed region. The three types of ruby and sapphire recognized at this occurrence are likely to be found in other gem corundum deposits in the southern Ural Mountains. In addition, these corundum deposits have gemological and geologic similarities in common with important deposits elsewhere, such as the ruby and spinel deposits of Mogok, Myanmar (Burma). Therefore, the geologic model for the formation of gem corundum at Kootchinskoye should help in future exploration for rubies and sapphires in marbles.

To date, there is no commercial production of ruby and sapphire in this region, although two large Russian companies recently obtained licenses to mine in the area. A newly discovered occurrence at Lipovskoye, in the central Urals, also shows promise (figure 10). The author believes that there are significant reserves in the area.

\section{REFERENCES}

Barbot de Marny N. (1855) Mineral occurrences in Uralian placcrs. Gornit Jurnal (Mining Journal), Vol. 2, pp. $75-85$ (in Russian).

Boltyrov V.B., Pystin A.M., Ogorodnikov V.N. (1973) Regional metamorphism of the northern margins of the Sanarskii granite complex in the southern Urals. Geology of Metamorphic Complexes of the Urals, Sverdlovsk Mining Institute Publication No.91, pp. 53-66 (in Russian).

Gübelin E.J. \{1982\} Gemstones of Pakistan: Emerald, ruby and spinel. Gems e) Gemology, Vol. 18, No. 3, pp. 123-139.

Hänni H.A., Schmetzer K. (1991) Ncw rubics from the

Morogoro area, Tanzania. Gems es Gemology, Vol. 27, No. 3, pp. $156-167$.

Iyer L.A.N. (1953) Memoirs of the Geological Survey of India, Volume 82, The Geology and Gemstones of the Mogok Stone Tract, Burma. Government of India Press, Calcutta, $100 \mathrm{pp}$.

Janscn J.B.H., Feenstra A., Schuiling R.D. (1978) A spinel-forming reaction in aluminous dolomitic marbles of Naxos, Greece. Neues Jahrbuch für Mineralogie, Monatshefte, Vol. 1978, No. 4, pp. 145-158.

Kane R.E., Kammerling R.C. (1992) Status of ruby and sapphire mining in the Mogok Stone Tract. Gems $\Leftrightarrow$ Gemology, Vol. 28, No. 3, pp. 152-174. 
Keller P.C. \{1983\} The rubies of Burma: A revicw of the Mogok Stone Tract. Gems e) Gemology, Vol. 19, No. 4, pp. 209-219. Kievlenko E.l., Senkcvich N.N., Gavrilov A.P. (1974) Geology of Gemstone Deposits. Nedra, Moscow (in Russian).

Kissin A.J. (1990a) The Uralian ruby-bearing province. Abstracts of the Second Regional Mineralogical Conference, Mineralogia Urala, Miass., Sverdlovsk Academy of Sciences Publications, Vol. 2, pp. 120-123 (in Russian).

Kissin A.J. (1990b) The formation of ruby-bearing marbles. Abstracts of the 12th USSR Precambrian Metallogenic Conference, Precambrian Metalliferous and Metamorphic Ore Formations, part 2, Nauka, Kiev pp. 221-222, (in Russian)

Kissin A.J. (1991) Ruby Deposits in Mables (Uralian Material). Russian Academy of Scicnces, Uralian Branch, Sverdlovsk (in Russian).

Kissin A.J., Talantsev A.S. (1986) The conditions of formation of chondrodite-tremolite veinlets in the marble deposits associated with the Kochkar granitic intrusion. Zapiski Vsesoiuznogo Mineralogicheskogo Obshchestva (The USSR Mineralogical Association Reports), Vol. 115, No. 1, pp. 93-99 (in Russian).
Koksharov N.l. (1855) The mincralogy of Russia. Gornii furnal (Mining Journal), Vol. 4, p. 261 (in Russian).

Okrusch M., Bunch T.E., Bank H. (1976) Paragenesis and petrogenesis of a corundum-bearing marble at Hunza (Kashmir). Mineralium Deposita, Vol. 11, pp. 278-297.

Pcrtsev N.N. (1977) High-Temperature Metamorphism and Metasomatism in Carbonate-bearing Rocks. Nedra Moscow (in Russian).

Rossovskii L.N. (1980) Deposits of precious stones in Afghanistan. Geologia Rudnih Mestorozhdenii /Geology of Ore Deposits\}, Vol. 22, No. 3, USSR Acadcmy of Sciences, Moscow, pp. 74-88 (in Russian).

Rossovskii L.N., Konovalcnko S.l., Anaicv S.A. (1982) Conditions for the formation of rubies in marblcs. Geologia Rudnih Mestorozhdenii (Geology of Ore Deposits), Vol. 24, No. 2. pp. 57-66, USSR Academy of Sciences, Moscow (in Russian).

Talantsev A.S. (1981) Geothermobarometer for the Dolomite Calcitic Paragenesis. Nauka, Moscow (in Russian).

Thordarsson H. (1981) The reaction corundum + dolomite = spinel + calcite. Geologiska Föreningens I Stockholm Förhandlingar, Vol. 103, No. 1, pp. 127--128.

\section{AN EXCEPTIONAL BOOK- At An Exceptional Price!}
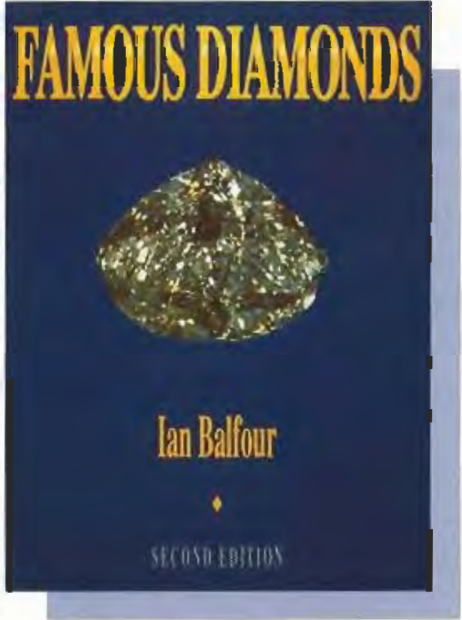

Famous Diamonds 2nd Fitition-Ian Balfour 245 pages, 200 photographs

\section{Only \$39.95!}

Regular Price $\$ 49.95$.

Offer valid while supplies last.
W ith access to society's most privileged circles, Lord Balfour has researched and photographed over 100 of the world's rarest diamonds. Famous Diamonds is the most comprehensive art/reference book on diamonds of exceptional color, size, beauty and historical background.

Exquisitely photographed and authoritatively documented, Famous Diamonds separates historical fact from popular legend. This 2 nd edition covers a wide range of memorable diamonds - from the most recognized, like the Hope Diamond, to the most recently discovered, such as the Centenary and AGRA. No diamond library is complete without it.

To order Famous Diamonds or

For a FREE comprehensive GIA Bookstore catalog

Call Toll-Free 800-421-7250, Ext. 282

Outside the U.S. 310-829-2991, Ext. 282 or FAX: 310-449-1161

GGFD 5

\section{B. Bookstore 1660 Stewart Street, SANTA Monica, CA 90404}

